\title{
PEMANFAATAN MEDIA KOMUNIKASI DAN INFORMASI DALAM PERWUJUDAN PEMBANGUNAN NASIONAL
}

\section{Utilization of Communication Media and Information for Embody National Development}

Dharlinda Suri

STKIP PGRI Bandar Lampung

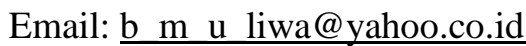

\begin{abstract}
This scientific work is the result of the analysis and study of literature that reviews the communication and information media, namely social media in the form of social networks as a very effective medium used as a medium of communication and information to convey problems or aspirations of the community, especially for regions that have not been touched by the media optimally. widely known by the general public, especially officials who are currently serving. This study has a purpose for: first, to describe the characteristics of digital age society that uses communication media. Second, describing the linkages of the media of communication with national development and Third, describing the opportunities and challenges that arise in the digital era society. And fourth, describe the efforts that must be done in the digital era.This research method is a descriptive study with a qualitative approach. Researchers conduct data collection in accordance with existing events. Then the data is analyzed by means of data collection, data reduction, data presentation then drawing conclusions or verification. The results of the study show that national development will be well realized if there is a communication medium in the form of social networks that are used by the community correctly, ethically and can be accounted for. This can be reached in the wider community with the existence of cooperation between the community and the local government, namely by conducting counseling in all places evenly.
\end{abstract}

Keywords: utilization of communication media, information, national development

\begin{abstract}
ABSTRAK
Karya ilmiah ini merupakan hasil analisis dan studi literatur yang mengulas tentang media komunikasi dan informasi yaitu media sosial dalam bentuk jejaring sosial sebagai media yang sangat efektif dijadikan media komunikasi dan informasi untuk menyampaikan masalah atau aspirasi masyarakat khususnya untuk daerah yang belum tersentuh media secara maksimal dan belum banyak diketahui oleh masyarakat luas khususnya pejabat-pejabat daerah yang sedang menjabat. Penelitian ini memiliki tujuan untuk: pertama, mendeskripsikan karakteristik masyarakat eradigital yang menggunakan media komunikasi. Kedua, mendeskripsikan keterkaitan media komunikasi dengan pembangunan nasional dan Ketiga,mendeskripsikan peluang dan tantangan yang timbul pada masyarakat era digital. Dankeempat, mendeskripsikan upaya yang harus dilakukan pada era digital. Metode penelitian ini merupakan penelitian deskriptif dengan pendekatan kualitatif. Peneliti melakukan pengumpulan data yang ada sesuai dengan peristiwa yang ada. Kemudian data dianalisis dengan cara pengumpulan data, reduksi data, penyajian data kemudian menarik kesimpulan atau verifikasi. Hasil penelitian menunjukan bahwa pembangunan nasional akan terwujud dengan baik apabila adanya suatu media komunikasi yang berbentuk jejaring sosial yang digunakan masyarakat dengan benar, beretika dan dapat dipertanggungjawabkan kebenaranya. Hal ini dapat sampai di masyarakat luas dengan adanya kerjasama antara masyarakat dengan pemerintah setempat yaitu dengan mengadakan penyuluhan di semua tempat secara merata.
\end{abstract}

Kata kunci: pemanfaatan media komunikasi, informasi, pembangunan nasional 


\section{PENDAHULUAN}

Pembangunan dalam beberapa dekade ini sebagian besartergantung pada apakah dan bagaimana masyarakat mempunyai aksesterhadap informasi. Agar dapat mempunyai pendapat dalam prioritaspengeluaran dan membuat pemerintah mereka bertanggungjawab,penduduk perlu menjadi peserta aktif. Hal ini penting secara khusus terkaitdengan kelompok-kelompok dan komunitas yang dimarjinalkan, apakahkarena kemiskinan, difabel atau diskriminasi gender, di antaranya.Kebanyakan orang-orang tergantung pada media untuk sebagian besarinformasi, dan ini pada akhirnya memerlukan suatu media yang mengalami pemberdayaan, profesional, dan dekat dengan komunitas mereka sehinggamereka dapat memberitahukan dan menjelaskan kebijakan-kebijakan danprioritas pemerintah dengan cara dimana semua orang dapat mengerti.Walaupun di masa lalu kepercayaan merupakan peninggalan utamamedia, sekarang ini teknologi baru telah membuka wawasan untuk aksespublik yang lebih luas. Apabila media tradisional mematuhi standar-standarprofesional dan beretika tinggi, maka caracara dan alat-alat tersebut dapat digunakan dan dimanfaatkan sebagai media baru yang secara positif dapat meningkatkan aksesterhadap informasi dan pemberdayaan masyarakat, maka demokrasi akanmenjadi suatu proses lebih bermakna bagi penduduk, dan pemerintahdapat diminta pertanggungjawabannya.

Informasi merupakan sesuatu yang mendasar bagi pengetahuan, danpenduduk yang terdidik dan berpengetahuan adalah penduduk yangmengalami pemberdayaan dan oleh karena itu dapat berpartisipasi dalamurusan penduduk, pembangunan sosial, dan kemajuan. Hak publik untukmenikmati kebebasan berekspresi dan akses terhadap informasi merupakanhal yang penting untuk mengkonsolidasikan dan membangun masyarakatyang demokratis, sipil, dan sehat yang menghargai hak-hak manusia danbenar-benar melayani publik. Konsep strategis penulis adalah "Masyarakat yang Terdidik adalah Masyarakat yang Mempunyai Kekuatan”. Harapannya pemberdayaan pemuda lokal yang menggunakan teknologi baru dapat membantu melayani komunitas masyarakat yang lokal dan terpencil, karena selama ini Media besar dan utama tidak melayani komunitas lokal sebagaimana saluran media yang berlokasi di kota-kota pusat provinsi tidak menjangkau desa-desa terpencil. Penyiar publik tidak mempunyai cabang-cabang di provinsi-provinsi dan laporan mereka dari wilayah-wilayah itu terjadi hanya sekali-sekali. Populasi lokal lebih mengetahui isu-isu nasional dari pada masalah dan tantangan lokal mereka.

Keadaan masyarakat masa saat ini yangmengandung berbagai kemungkinan tersebut menjadi peluang dan tantangan tersendiriyang justru perlu dipelajari dan masih mungkin untuk dapat direncanakan. Era digital sudah menyatu dengan kondisi masyarakat saat ini. Kondisi demikian menyebabkanmasyarakat semakin mudah dan memiliki peluang yang lebih besar dalam mengaksesberbagai informasi, terlebih lagi salah satu manfaat dari teknologi informasi yang mampumemanfaatkan keterbatasan ruang dan waktu. Masyarakat semakin dimanjakan denganadanya perkembangan teknologi yang begitu pesat karena semakin mudah dan cepatdalam mengakses teknologi terbaru, maka penyebaran informasi juga semakin cepat.Sebab itu, penting kiranya kita mempelajari dan mengantisipasi keadaan masyarakatmasa depan ini beserta implikasinya terhadap pembangunan. Karena hanya dengan upayapemberdayaan yang tepat diharapkan para masyarakat dapat terbentengi dari berbagaikemungkinan yang bisa saja muncul sebagai dampak dari era digital. 
Di era digital ini perkembangan teknologi terjadi sebuah evolusi pada teknologi media, sebut saja new media atau orang juga sering menyebutnya media online atau orang lebih akrab lagi menyebutnya dengan istilah internet, media ini tentunya sudah tidak asing lagi di telinga. Media ini juga disebut-sebut sebagai media yang sampai saat ini belum ada yang menandingi pertumbuhan jumlah penggunanya. Di negara maju, new media mengalahkan berbagai media yang sebelumnya telah dijadikan sumber referensi dalam mendapatkan sebuah informasi. Istilah new media muncul pada akhir abad 20, istilah ini digunakan untuk menyebut media jenis baru yang menggabungkan antara media konvensional dengan media internet. Dalam kurun waktu beberapa tahun belakangan ini new media diramaikan oleh fenomena munculnya situs jejaring sosial, situs ini menyediakan tempat didunia maya untuk membangun suatu komunitas jejaring pertemanan yang dapat diakses oleh semua orang di seluruh dunia.

Media interaktif memungkinkan terjadinya arus informasi timbal balik yang memungkinkan pengguna dapat berpartisipasi dan memodifikasi isi dari informasi pada saat itu juga (real time) (Morissan, 2010:24). Kemampuan interaktif ini juga dimiliki oleh jejaring sosial seperti Facebook dan jejaring sosial lain, ini lah yang membuat media online lebih unggul lagi dibanding media tradisional yang hanya bersifat satu arah dalam menyampaikan pesan komunikasinya. Pada media jejaring sosial seperti Facebook mampu memberikan feedback secara langsung sehingga tercipta komunikasi antar pribadi.

Adapun tujuan dalam pembahasan ini adalah untuk 1) mendeskripsikan karakteristik masyarakat era digital yang menggunakan media komunikasi, 2) mendeskripsikan keterkaitan media komunikasi dengan pembangunan nasional, 3) mendeskripsikan peluang dan tantangan yang timbul pada masyarakat era digital, dan 4) mendeskripsikan upaya yang harus dilakukan pada era digital.

\section{TINJAUAN PUSTAKA}

\section{Media Sosial Facebook}

Facebook begitu cepat beradaptasi dengan perkembangan teknologi yang populer ini merupakan nilai tambah bagi Facebook yang lengkap dengan fitur chatting dan status pengguna aktif menjadi fasilitas yang mampu menghidupkan situs jejaring sosial ini, dengan fitur chatting ini pengguna Facebook dapat berinteraksi dua arah secara langsung dan fitur pengguna aktif adalah untuk mengetahui teman-teman yang sedang online. Dengan situs jejaring sosial Facebook beberapa hal yang tidak mampu dilakukan oleh situs jejaring lainya Facebook mampu melakukannya karena Facebook dibekali dengan fitur-fitur canggih dan lebih aman, mulai berbagai informasi, berbagi foto, berbagai video dan banyak lagi hal-hal menarik lainnya. Bahkan para pengguna yang sedang giat dalam melakukan promosi produk dan jasa atau sedang melakukan kegiatan komunikasi pemasaran Facebook menjadi sales yang handal dalam membantu pengenalan produk dan jasa yang ditawarkan (Madcoms, 2010:1)

Hal ini dilatarbelakangi oleh banyaknya orang yang mengakses Facebook dan karena jangkauan Facebook yang luas dan diakses kapanpun dan dimanapun selain dapat diakses dengan perangkat komputer Facebook juga diaskes lewat ponsel ataupun tablet, oleh karena itu Facebook dimanfaatkan sebagai media komunikasi pemasaran yang sangat efektif dan sangat efisien. Saat ini banyak hal 
yang terjadi baik yang positif maupun negatif yang disebabkan oleh media komunikasi dalam bentuk jejaring sosial Facebook dan situs jejaring sosial lainya. Banyak masyarakat yang tidak memilih dan menyaring informasi secara baik dalam penyebaran informasi, baik informasi masalah individu, masalah masyarakat di lingkungan, masalah pembangunan maupun masalah pemerintahan. Seharusnya masyarakat lebih jeli dalam penyebaran berbagai informasi dalam hal layak umum. Apabila masyarakat tidak dapat beretika secara baik dalam menggunakan media komunikasi dalam bentuk jejaring sosial dengan baik akan banyak terjadi masalah - masalah dilingkungan masyarakat dan utamanya menjadi permusuhan antar individu di dalam negara sendiri. Saat ini pengguna jejaring sosial berdasarkan data dari kominfo menunjukan bahwa pengguna media komunikasi dalam bentuk jejaring facebook lebih unggul. Berikut data kominfo penggunaan media komunikasi dalam bentuk jejaring sosial di Indonesia.

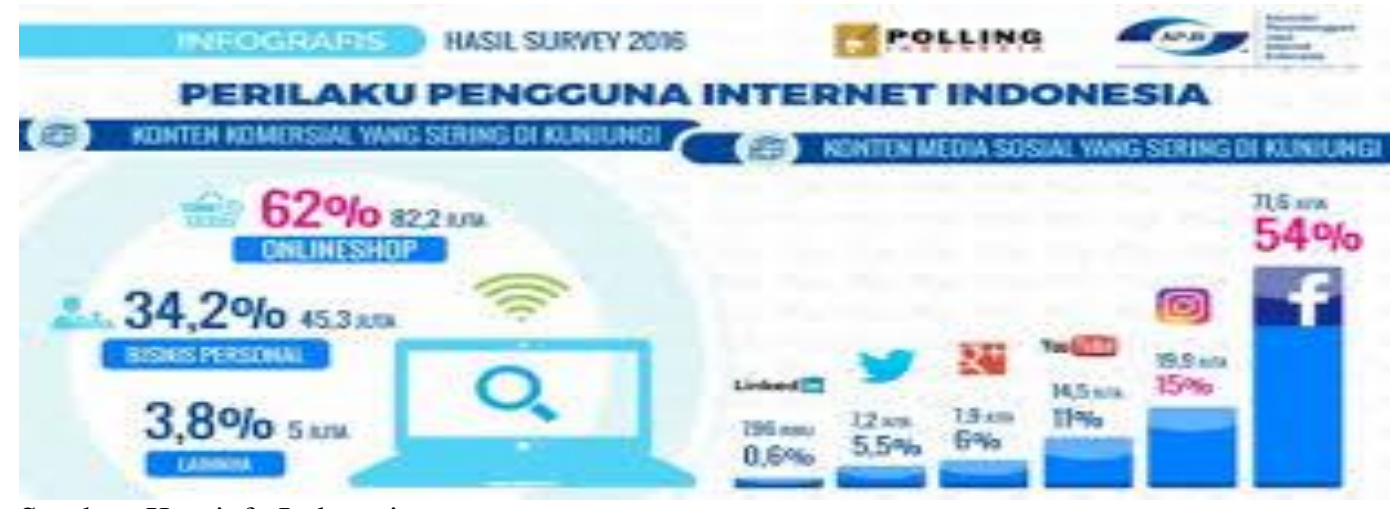

Sumber: Kominfo Indonesia

Gambar 1 Perilaku pengguna internet di Indonesia.

Berdasarkan hal tersebut menunjukan bahwa pengguna media komunikasi dalam bentuk jejaring sosial sangatlah tinggi. Sehingga masyarakat perlu di bina dan diberikan penyuluhan bagaimana penggunaan media komunikasi dalam bentuk jejaring sosial yang baik dan beretika, karena hal ini sangat berpengaruh terhadap kemajuan pembangunan nasional Indonesia. Berikut beberapa etika yang harus di ketahui oleh masyarakat sebagai pengguna media komunikasi dalam bentuk jejaring sosial.

\section{Etika dalam berkomunikasi}

Pada saat melakukan komunikasi dengan memanfaatkan media sosial, biasanya banyak yang cenderung melupakan etika dalam berkomunikasi. Hal ini di buktikan dengan banyaknya kata-kata kasar yang kerap kali muncul pada saat melakukan percakapan melalui jejaring sosial, baik yang sengaja dan tidak sengaja. Alangkah baiknya apabila sedang melakukan komunikasi pada jaringan internet menggunakan Bahasa yang sopan dan layak. Biasakanlah untuk menggunakan Bahasa yang tepat dengan siapapun pada saat kita berinteraksi, termasuk saat berinteraksi melalui media sosial.

\section{Hindari penyebaran SARA, pornografi dan aksi kekerasan}

Alangkah baiknya apabila kita tidak menyebarkan informasi yang mengandung unsur SARA (Suku, Agama dan Ras) serta pornografi pada jejaring sosial. Biasakan untuk menyebarkan hal-hal yang berguna dan tidak menimbulkan konflik antar sesama. Hindari juga mengupload foto kekerasan seperti foto korban kekerasan, foto kecelakaan lalu lintas maupun foto kekerasan dalam bentuk 
lainnya. Jangan menambah kesedihan para keluarga korban dengan menyebarluaskan foto kekerasan karena mungkin saja salah satu dari keluarganya berada di dalam foto yang Anda share. Jangan mengajarkan generasi muda mengenai hal kekerasan melalui foto kekerasan yang di upload secara terangterangan pada media sosial.

\section{Kroscek kebenaran berita}

Saat ini tentu tidak jarang kalau kita menemukan berita yang menjelekan salah satu pihak di media sosial. Hal inilah yang terkadang bertujuan demi menjatuhkan nama pesaing dengan menyebarkan berita yang hasil rekayasa. Maka dari itu, pengguna media sosial dituntut agar lebih cerdas lagi saat menangkap sebuah informasi, apabila Anda ingin menyebarkan informasi tersebut, alangkah bijaknya jika Anda melakukan kroscek terlebih dahulu atas kebenaran informasi tersebut.

\section{Menghargai hasil karya orang lain}

Pada saat menyebarka informasi baik dalam bentuk foto, tulisan maupun video milik orang lain maka biasakan untuk mencantumkan sumber informasi sebagai salah satu bentuk penghargaan atas hasil karya seseorang. Jangan membiasakan diri untuk serta merta mengcopy-paste tanpa mencantumkan sumber informasi tersebut.

\section{Jangan terlalu mengumbar informasi pribadi}

Ada baiknya Anda harus bersikap bijak dalam menyebarkan informasi mengenai kehidupan pribadi (privasi) Anda saat sedang menggunakan media sosial. Janganlah terlalu mengumbar informasi pribadi Anda terlebih lagi informasi mengenai nomor telepon atau alamat rumah Anda. Hal tersebut bisa saja membuat kontak lain dalam daftar Anda juga akan menjadi informasi bagi mereka yang ingin melakukan tindak kejahatan kepada diri Anda.

\section{METODE PENELITIAN}

Penelitian ini merupakan penelitian deskriptif dengan pendekatan kualitatif. Peneliti melakukan pengumpulan data yang ada sesuai dengan peristiwa yang ada. Sumber data penelitian ini diperoleh melalui studi literatur. Kemudian data dianalisis dengan cara pengumpulan data, reduksi data, penyajian datakemudian menarik kesimpulan atau verifikasi.

\section{HASIL DAN PEMBAHASAN}

\section{Karakteristik masyarakat era digital}

Masalah yang muncul ke permukaan mengenai pemahaman masyarakat eradigital yakni mengenai sejauh mana definisi masyarakat era digital memperoleh porsiyang tepat dalam seluruh konteks perkembangan masyarakat secara luas. Pada dasarnyasebutan masyarakat era digital telah melekat dengan sendirinya pada situasi masyarakatyang telah ada. Merupakan suatu kenyataan bahwa setiap individu mempunyaikebutuhan dan tuntutan terhadap teknologi informasi. Perkembangan dinamikakemanusiaan menempatkan perkembangan teknologi informasi dalam konteksmasyarakat era digital menjadi suatu kenyataan bahkan keharusan. 
Indonesia hanya membutuhkan beberapa dekade saja pascakemerdekaan untukmenciptakan masyarakat era digital. Masyarakat era digital merupakan masyarakat yangmampu mengaplikasikan teknologi informasi ke dalam kesehariannya. Tanda yangsignifikan dalam masyarakat era digital saat ini adalah perkembangan yang sangat cepatpada sektor ilmu pengetahuan dan teknologi. Tantangan era digital di Indonesiautamanya yakni bangsa Indonesia harus berusaha menyetarakan atau mengikutiperkembangan zaman akan perkembangan teknologi dunia, karena perkembanganteknologi dan informasi sangat pesat. Bangsa Indonesia harus meningkatkankreatifitasnya dalam dunia teknologi agar dapat mengikuti perkembangan zaman yangsekarang ini dalam kondisi yang serba mutakhir. Hal ini tentu akan memberikan dampakyang sangat besar bagi dunia pendidikan khususnya terkait peluang dan tantangan kedepannya.

\section{Keterkaitan media komunikasi dengan pembangunan nasional}

Agar komunikasi pembangunan lebih berhasil mencapai sasarannya, serta dapat menghindarkan kemungkinan-kemungkinan efek yang tidak diinginkan, tentunya harus mempertimbangkan hal-hal. Kesenjangan efek yang ditimbulkan oleh kekeliruan cara-cara komunikasi selama ini, menurut Rogers dan Adhikarya (1978) dapat diperkecil bila strategi komunikasi pembangunan dirumuskan demikiaan rupa, mencakup prinsip-prinsip sebagai berikut:

1. Penggunaan pesan yang dirancang khusus (tailored messages) untuk khalayak yang spesifik. Misalnya, bila hendak menjangkau khalayak miskin pada perumusan pesan, tingkat bahasa, gaya penyajian, dan sebagainya, disusun begitu rupa agar dapat dimengerti dan serasi dengan kondisi mereka.

2. Pendekatan ceiling effect yaitu pendekatan dengan mengomunikasikan pesanpesan yang bagi golongan yang tidak dituju, katakanlah golongan atas, merupakan "redundansi" (tidak lagi begitu berguna karena sudah dilampaui mereka) atau kecil manfaatnya, namun tetp berfaedah bagi golongan khalayak yang hendak dijangkau. Dengan cara ini, dimaksudkan, agar golongan khalayak yang benar-benar berkepentingan tersebut mempunyai kesempatan untuk mengejar ketertinggalanya, dan dengan demikian dapat mempersempit jarak efek komunikasi yang telah disinggung diatas tadi.

3. Penggunan Pendekatan Narrow Casting atau melokalisasi penyampaian pesan bagi kepentingan khalayak. Lokalisasi disini berarti disesuaikannya penyampaian informasi yang dimaksud dengan situasi kesempatan dimana khalayak berada.

4. Pemanfaatan saluran tradisional, yaitu berbagai bentuk pertunjukan rakyat yang sejak lama memamg berfungsi sebagai saluran pesan yang akrab dengan masyarakat setempat.

5. Pengenalan para pemimpin opini dikalangan lapisan masyarakat yang berkekurangan (disadvantage), dan meminta bantuan mereka untuk menolong mengomunikasikan pesan-pesan pembangunan.

6. Mengaktifkan keikutsertaan agen-agen perubahan yang berasal dari kalangan masyarakat sendiri sebagai petugas lembaga pembangunan yang beroperasi dikalangan rekan sejawat mereka sendiri.

7. Diciptakan dan dibina cara-cara atau mekanisme bagi keikutsertaan khlayak, sebagai pelaku-pelaku pembangunan itu sendiri, dalam proses pembangunan yaitu sejak tahap perencanaan sampai evaluasinya.

Perkembangan pemikiran mengenai pemanfaatan dan peranan komunikasi dalam melaksanakan usaha membangun masyarakat memperlihatkan hubungan 
yang langsung dengan konsepsi yang dianut dalam merencanakan dan menafsirkan "pembangunan" itu sendiri. Dengan demikian, rumusan tentang pemanfaatn komunikasi ataupun peran yang diharapkan darinya dalam suatu usaha pembangunan amat ditentukan oleh model pembangunan yang dilaksanakan itu sendiri (Nasution, 2002).

Konsepsi-konsepsi pembangunan yang lebih baru mencakup suatu peranan yang berbeda, dan pada umumnya lebih besar bagi komunikasi (Rogers, 1976). Pengerahan massa melalui organisasi sosial pada tingkat lokal amat tergantung pada komunikasi dan dengan cara yang samasekali berbeda dengan pendekatan industrialisai terhadap pembangunan.

Komunikasi berperan penting dalam pembangunan. Apabila kita menengok ke belakang, sarana komunikasi di negara-negara berkembang yang dulunya masih terbatas pada media cetak, semuanya kini telah berubah. Teknologi komunikasi mulai berkembang pesat, terutama dengan adanya televisi, internet, dan telepon. Perkembangan ini menyebabkan "jarak psikologis" mendekatkan "jarak geografis" antar bangsa. Namun di sebagian negara sedang berkembang, masih terdapat ketimpangan informasi dalam sistem komunikasi mereka. Ketimpangan komunikasi tersebut dapat menimbulkan perbedaan persepsi tentang pembangunan, yang pada akhirnya menghambat pembangunan itu sendiri.

Komunikasi pembangunan bersifat timbal balik mementingkan adanya dialog antara kedua belah pihak yang memberikan penerangan atau yang menyampaikan pesan dengan pihak yang menerima pesan/penerangan, dan antara khalayak sendiri. Menurut Hedebro (1979) mengidentifikasi tiga aspek komunikasi dan pembangunan yang berkaitan dengan tingkat analisisnya, yaitu :

1. Pendekatan yang berfokus pada pembangunan suatu bangsa dan bagaimana media komunikasi dapat menyumbang dalam upaya tersebut.

2. Pendekatan yang memahami peranan media massa dalam pembangunan nasional.

3. Pendekatan yang berorientasi kepada perubahan yang terjadi pada suatu komunitas lokal atau desa.

Dalam karyanya Schramm (1964) merumuskan tugas pokok komunikasi dalam suatu pembangunan sosial dalam rangka pembangunan nasional, yaitu :

1. Menyampaikan informasi tentang pembangunan nasional kepada masyarakat

2. Memberikan kesempatan untuk mengambil bagian secara aktif dalam proses pembuatan keputusan kepada masyarakat.

3. Mendidik tenaga kerja yang diperlukan pembangunan-pembangunan.

Catatan tentang peranan komunikasi dalam pembangunan ini masih dapat diperpanjang. Terutama karena semakin kompleksnya tuntutan pembangunan itu sendiri dan berbagai ulasan yang dikemukakan para ahli, Hedebro (1979) mendaftar 12 peran yang dapat dilakukan komunikasi dalam pembangunan, yakni:

1. Komunikasi dapat menciptakan iklim dari perubahan dengan membujukkan nilai-nilai, sikap mental dan bentuk perilaku yang menunjang modernisasi.

2. Komunikasi dapat mengajarkan keterampilan-keterampilan baru

3. Media massa dapat bertindak sebagai pengganda sumber-sumber pengetahuan

4. Media massa dapat mengantarkan pengalaman-pengalaman sehingga mengurangi biaya psikis dan ekonomis untuk menciptakan kepribadian

5. Komunikasi dapat meningkatkan aspirasi yang merupakan perangsang untuk bertindak nyata 
6. Komunikasi dapat membantu masyarakat menemukan norma-norma baru dan pembuatan keputusan di tengah kehidupan masyarakat

7. Komunikasi dapat membuat orang lebih condong untuk berpartisipasi dalam pembuatan keputusan

8. Komunikasi dapat mengubah struktur kekuasaan pada masyarakat

9. Komunikasi dapat menciptakan rasa kebangsaan sebagai sesuatu yang mengatasi kesetian-kesetian lokal

10. Komunikasi dapat membantu mayoritas populasi menyadari pentingnya arti mereka sebagai warga negara

11. Komunikasi memudahkan perencanaan dan implementasi program-program pembangunan

12. Komunikasi dapat membuat pembangunan ekonomi, sosial, dan politik menjadi suatu proses yang berlangsung sendiri (self-perpetueting)

Penerapan komunikasi pembangunan di sektor kehidupan yang menunjukkan kesamaan sejumlah karakteristik antara lain :

1. Menerapkan prinsip, sistem, dan teknologi komunikasi, sebagai salah satu komponen yang tergolong utama dalam pencapaian tujuan kegiatannya.

2. Memberikan peranan yang terbilang penting bagi komunikasi didalam rangkaian struktur kegiatan pembangunan yang bersangkutan.

3. Menggunakan dan mengembangkan metodologi serta pendekatan yang sistemik dalam pemanfaatan komunikasi pada lingkup kegiatannya.

4. Memperlihatkan kesinambungan dan saling belajar dari pengalaman di bidang yang lain khususnya dalam hal pemanfaatan teknologi komunikasi.

Hassan, seperti yang dikutip Jahi (1988: 111),menunjukkan bahwa ada tiga fungsi media massadalam pembangunan, yaitu:

1. Memberi tahu rakyat tentang pembangunannasional, memusatkan perhatian mereka padakebutuhan untuk berubah, kesempatan untukmenimbulkan perubahan, metoda dan caramenimbulkan perubahan, dan jika mungkin meningkatkan aspirasi.

2. Membantu rakyat berpartisipasi dalam proses pembuatan keputusan, memperluas dialog danmenjaga agar informasi mengalir baik ke atasmaupun ke bawah.

3. Mendidik rakyat agar memiliki keterampilan.Ketiga fungsi media itu, sepadan dengan pendapat Chalkley yang dikutip Medis (dalam Jahi,1988: 112), tentang peranan media massa yang dapat diberikan dalam pembangunan model partisipatif, yaitu :

a. Memberi tahu masyarakat tentang faktakehidupan ekonomi mereka.

b. Menginterpretasikan fakta tersebut agar dapatdipahami oleh masyarakat itu dan kemudian mempromosikan hal tersebut agar masyarakat menyadari betapa serius masalah pembangunan yang mereka hadapi dan memikirkan lebih lanjut masalah itu, serta menyadarkan mereka pada solusi-solusi yang mungkin ditempuh.

c. Meskipun peranannya terbatas, komunikasi tidak boleh diperlakukan sekadar kegiatan penunjang pembangunan. Komunikasi harus dijadikan salah satu komponen pembangunan,sama seperti komponen-komponen lainnya, kalau tidak ingin mendapatkan kesulitan besar dikemudian hari.

\section{Peluang dan tantangan yang timbul pada masyarakat era digital}

Dunia digital tidak hanya menawarkan peluang dan manfaat besar bagi publik dan kepentingan bisnis. Namun juga memberikan tantangan terhadap 
segala bidang kehidupan untuk meningkatkan kualitas dan efisiensi dalam kehidupan.Penggunaan bermacam teknologi memang sangat memudahkan kehidupan, namun gaya hidup digital pun akan makin bergantung pada penggunaan ponsel dan komputer. Apapun itu, kita patut bersyukur semua teknologi ini makin memudahkan, hanya saja tentunya setiap penggunaan mengharuskannya untuk mengontrol serta mengendalikannya. Karena bila terlalu berlebihan dalam menggunakan teknologi ini kita sendiri yang akan dirugikan, dan mungkin juga kita tak dapat memaksimalkannya.

Perkembangan teknologi yang begitu cepat hingga merasuk di seluruh lini kehidupan sosial masyarakat, ternyata bukan saja mengubah tatanan kehidupan sosial, budaya masyarakat tetapi juga kehidupan politik. Kecanggihan teknologi yang dikembangkan oleh manusia benar-benar dimanfaatkan oleh para politisi yang ingin meraih simpati, dan empati dari masyarakat luas. Untuk menaikan elektabilitas dan popularitas dapat dilakukan dengan fasilitas digital seperti salah menghubungkan dengan pelanggan, dan alat-alat produktivitas. Tantangan dalam bidang teknologi informasi sangat banyak seperti memecahkan suatu masalah, membuka kreativitas, meningkatkan efektivitas dan efisiensi dalam melakukan pekerjaan.

Tantangan yang besar dihadapi oleh masyarakat saat ini adalah masyarakat kurang dapat mengendalikan diri atau mengontrol diri dalam penggunaan media komunikasi khususnya bentuk jejaring sosial. Banyak masyarakat yang mudah terpengaruh dan menyebarkan berita atau informasi yang belum jelas kebenaranya. Atau masyarakat menyebutnya hoax. Sehingga dalam hal ini etika pengunaan media komunikasi perlu di berikan melalui penyuluhan dari pihak pihak yang terkait.

\section{Upaya Yang Harus di Lakukan pada Era Digital}

Era digital harus disikapi dengan serius,menguasai, dan mengendalikan peran teknologi dengan baik agar era digital membawa manfaat bagi kehidupan. Pendidikan harus menjadi media utama untuk memahami, mengusai, dan memperlakukan teknologi dengan baik dan benar. Anak-anak dan remaja harus difahamkan dengan era digital ini baik manfaat maupun madharatnya. Orang tua harus pula difahamkan agar dapat mengonrol sikap anak-anaknya terhadap teknologi dan memperlakukannya atau menggunakannya dengan baik dan benar.

Pengenalan tentang pemanfaatan berbagai aplikasi yang dapat membantu pekerjaan manusia perlu dikaji agar diketahui manfaat dan kegunaannya serta dapat memanfaatkannya secara efektif dan efisien terhindar dari dampak negatif dan berlebihan. Demikian juga pemerintah melakukan kajian mendalam era digital ini dalam berbagai bidang seperti politik, ekonomi, sosial budaya, pertahanan atau keamanan serta teknologi informasi.Namun disisi lain dunia anak sangat memprihatinkan khususnya pada perubahan karakter dan mental. Sikap anak-anak yang agresif dan kekerasan fisik sering disaksikan dalam pergaulan dengan sesamanya merupakan fenomena yang saling berhubungan.

Merosotnya nilai moral pada anak khususnya memang menjadi keprihatinan serius pemerintah dan masyarakat, namun di era serba digital sekarang dengan arus teknologi infomasi yang sulit dibendung menjadikan persoalan tersebut tidak sederhana. Media yang tanpa kontrol dapat dengan mudah mencuci otak anak melalui game online. Selain itu untuk masyarakat yang sudah dewasa dapat menyebarkan informasi yang belum tentu kebenaranya atau hoax. Sehingga perlu 
memahami etika dalam menggunakan media komunikasi. Etika penggunaan media komunikasi dalam bentuk jejaring sosial dapat dilakukan dengan memberikan penyuluhan kepada masyarakat di setiap kabupaten. Hal ini memiliki tujuan agar pembangunan nasional di indonesia dapat terlaksana dengan baik. Berikut etika yang harus diketahui oleh masyarakat luas dalam penggunaan media komunikasi yang baik untuk menyampaikan aspirasinya kepada pemerintah terkait pembangunan nasional.

\section{a. Etika dalam Berkomunikasi}

Pada saat melakukan komunikasi dengan memanfaatkan media sosial, biasanya banyak yang cenderung melupakan etika dalam berkomunikasi. Hal ini di buktikan dengan banyaknya kata-kata kasar yang kerap kali muncul pada saat melakukan percakapan melalui jejaring sosial, baik yang sengaja dan tidak sengaja.

Alangkah baiknya apabila sedang melakukan komunikasi pada jaringan internet menggunakan Bahasa yang sopan dan layak. Biasakanlah untuk menggunakan Bahasa yang tepat dengan siapapun pada saat kita berinteraksi, termasuk saat berinteraksi melalui media sosial.

\section{b. Hindari Penyebaran SARA, Pornografi dan Aksi Kekerasan}

Alangkah baiknya apabila kita tidak menyebarkan informasi yang mengandung unsur SARA (Suku, Agama dan Ras) serta pornografi pada jejaring sosial. Biasakan untuk menyebarkan hal-hal yang berguna dan tidak menimbulkan konflik antar sesama. Hindari juga mengupload foto kekerasan seperti foto korban kekerasan, foto kecelakaan lalu lintas maupun foto kekerasan dalam bentuk lainnya.

Jangan menambah kesedihan para keluarga korban dengan menyebarluaskan foto kekerasan karena mungkin saja salah satu dari keluarganya berada di dalam foto yang Anda share. Jangan mengajarkan generasi muda mengenai hal kekerasan melalui foto kekerasan yang di upload secara terangterangan pada media sosial.

\section{c. Kroscek Kebenaran Berita}

Saat ini tentu tidak jarang kalau kita menemukan berita yang menjelekan salah satu pihak di media sosial. Hal inilah yang terkadang bertujuan demi menjatuhkan nama pesaing dengan menyebarkan berita yang hasil rekayasa. Maka dari itu, pengguna media sosial dituntut agar lebih cerdas lagi saat menangkap sebuah informasi, apabila Anda ingin menyebarkan informasi tersebut, alangkah bijaknya jika Anda melakukan kroscek terlebih dahulu atas kebenaran informasi tersebut.

\section{d. Menghargai Hasil Karya Orang Lain}

Pada saat menyebarka informasi baik dalam bentuk foto, tulisan maupun video milik orang lain maka biasakan untuk mencantumkan sumber informasi sebagai salah satu bentuk penghargaan atas hasil karya seseorang. Jangan membiasakan diri untuk serta merta mengcopy-paste tanpa mencantumkan sumber informasi tersebut. 


\section{e. Jangan Terlalu Mengumbar Informasi Pribadi}

Ada baiknya Anda harus bersikap bijak dalam menyebarkan informasi mengenai kehidupan pribadi (privasi) Anda saat sedang menggunakan media sosial. Janganlah terlalu mengumbar informasi pribadi Anda terlebih lagi informasi mengenai nomor telepon atau alamat rumah Anda. Hal tersebut bisa saja membuat kontak lain dalam daftar Anda juga akan menjadi informasi bagi mereka yang ingin melakukan tindak kejahatan kepada diri Anda.

\section{KESIMPULAN DAN SARAN}

Kondisi masyarakat terus berubah dengan cepat, keadaan masyarakat era digitalmemiliki karakteristik yang berbeda daripada keadaan masyarakat di era sebelumnya. Hal tersebut memberikan implikasi secara langsung terhadap proses pembangunan nasional.

Pembangunan nasional dilihat dari SDM, tempat atau lingkungan masyarakat, dan pendidikan. Makadari itu, hendaknya pembangunan nasional yang mencakup SDM, tempat atau lingkungan masyarakat, dan pendidikan dapat memprediksi sekaligus mengendalikan penggunaan media komunikasi yang berlebihan dan tidak beretika dengan baik. Hal tersebut dapat terlaksana dengan baik apabila adanya suatu kerjasama antara masyarakat dengan pemerintah daerah setempat yaitu melalui penyuluhan terhadap masyarakat mengenai etika berkomunikasi dengan media komunikasi yang baik dan menyampaikan aspirasi serta persoalan yang terjadi di dalam masyarakat dengan cepat, benar dan dapat dipertanggung jawabkan kebenaranya. Serta beberapa hal yang dapat direkomendasikan kepada para pengambilkebijakan dan praktisi pendidikan.

\section{DAFTAR PUSTAKA}

Andy Corry Wardhani. 2002. Kontribusi Komunikasi Pada Teori Pembangunan. Jurnal Ilmiah Mediator.Bandung

http://download.portalgaruda.org/article.php?article=117055\&val=5336 diakses tanggal 4 Oktober 2018 pada pukul 10.00 WIB.

Gio Mohamad Johan dan Suyanto. 2010. Masyarakat Era Digital Dan Pendidikan: Antara Peluang Dan Tantangan. STKIP Bina Bangsa Getsempena. Banda Aceh.

Guy Berger, Dkk. 2015. Media Dalam Menunjang Pembangunan Berkelanjutan Dan Budaya Damai. Prosiding Unesco Office Jakarta

Haryanto. 2015. Pemanfaatan Media Sosial Sebagai Media Komunikasi Pustakawan Homogen Dalam Rangka Pemanfaatan Bersama Koleksi Antar Perguruan Tinggi. Universitas Sebelas Maret Surakarta. Surakarta.

Wawan setiawan. 2017. Era digital dan tantangnya. Universitas Pendidikan Indonesia. Seminar Nasional. Bandung. http://eprints.ummi.ac.id/151/ 2/1.\%20Era\%20Digita1\%20dan\%20Tantangannya.pdf, diakses tanggal 4 Oktober 2018 pada pukul 12.00 WIB. 